\title{
The Research of Heat Transfer Area for 55/19 Steam Generator
}

\author{
Qingsen Zhao, Debing Deng, Shenbin Nie, Wei Chen, Jiayong Wang, Ding Zhang \\ Suzhou Nuclear Power Research Institute, Suzhou, China \\ Email: zhaoqingsen@cgnpc.com.cn
}

Received December 2014

\begin{abstract}
A calculation method of heat transfer area for vertical natural circulated steam generator was introduced. According to the design requirements of steam generator 55/19 of CPR1000, its heat transfer area was calculated based on this method. The results show that the accuracy of partitional and overall calculation method is almost the same, but the result is different when using different calculation models. And the results are compared with the foreign companies for 55/19 steam generator.
\end{abstract}

\section{Keywords}

Steam Generator, Heat Transfer Area, 55/19

\section{Introduction}

Vertical, U-tubed and natural circulation steam generator, which is a key equipment of nuclear steam supply system (NSSS), is widely used in pressurized water reactor (PWR) system of nuclear plant. As the hub of primary loop and secondary Loop, its function is to transfer the primary loop heat to the coolant of secondary loop and produce steam to drive a turbine to generate electricity.

Computation of heat transfer area in the steam generator is the basis of thermal-hydraulic design and one of the important contents for a steam generator. The main purpose is to calculate the heat exchange area, which satisfies the heat exchange load between the coolants of primary and secondary loop. A proper heat exchange area of the steam generator has an important influence on its performance and economic benefit of the whole plant. Therefore, a right calculation method, suitable calculation models, and consideration of a certain amount of plugging and appropriate fouling resistance have great significance of ensuring the performance requirements of the steam generator during the entire design life.

This paper introduces a calculation method of the vertical, U-tubed and natural circulation steam generator, calculates the heat transfer area of steam generator 55/19 based on this model, and compares with the results of foreign companies.

\section{The Input Parameters}

The input parameters (known conditions) of the steam generator 55/19 heat transfer area calculation are lists in 
Table 1 [1]. Considering the $U$ tube fouling on the outside wall and the uncertainty of $U$ tube damage during late stage of the steam generator, the design tube plugging was $10 \%$, the $\mathrm{U}$ tube fouling coefficient is $88 \times 10^{-7}$ $\mathrm{m}^{2} \cdot \mathrm{K} / \mathrm{W}$.

\section{Calculation of Heat Transfer Area}

The heat transfer equation is as follows:

$$
\mathrm{P}_{\mathrm{t}}=\mathrm{q}_{\mathrm{m}, \mathrm{p}}\left(\mathrm{h}_{\mathrm{in}}-\mathrm{h}_{\text {out }}\right)
$$

where $\mathrm{P}_{\mathrm{t}}$ is the total thermal power, $\mathrm{kW} ; \mathrm{q}_{\mathrm{m}, \mathrm{p}}$ is the coolant flow rate, $\mathrm{kg} / \mathrm{s} ; \mathrm{h}_{\mathrm{in}}$ and $\mathrm{h}_{\text {out }}$ are the coolant enthalpies of inlet and outlet, $\mathrm{kJ} / \mathrm{kg}$.

Excluding blowdown energy loss, steam production calculated from the heat balance equation is showed that:

$$
\mathrm{q}_{\mathrm{m}, \mathrm{s}}=\eta_{\mathrm{sg}} \cdot \mathrm{P}_{\mathrm{t}} /\left(\mathrm{h}_{\mathrm{g}}-\mathrm{h}_{\mathrm{fw}}\right)
$$

where $\eta_{\mathrm{sg}}$ is thermal efficiency of the steam generator, $0.97-0.99 ; \mathrm{h}_{\mathrm{g}}$ and $\mathrm{h}_{\mathrm{fw}}$ are the steam enthalpy and the feed water enthalpy, $\mathrm{kJ} / \mathrm{kg}$.

The calculation equation of heat transfer area is shown that:

$$
\mathrm{A}=\frac{\mathrm{P}_{\mathrm{t}}}{\mathrm{K} \Delta \mathrm{t}_{\mathrm{m}}}
$$

where $\mathrm{K}$ is the Heat transfer coefficient, $\mathrm{W} / \mathrm{m}^{2} \cdot \mathrm{K} ; \Delta \mathrm{t}_{\mathrm{m}}$ is the logarithmic temperature difference of heat transfer, ${ }^{\circ} \mathrm{C}$.

According to the cylinder wall heat transfer theory [2]:

$$
\begin{aligned}
& \mathrm{K}=\frac{1}{\frac{1}{\alpha_{1}} \cdot \frac{\mathrm{d}_{\mathrm{e}}}{\mathrm{d}_{\mathrm{i}}}+\frac{1}{\alpha_{2}} \cdot \frac{\mathrm{d}_{\mathrm{e}}}{\mathrm{d}_{\mathrm{o}}}+\mathrm{R}_{w}+\mathrm{R}_{f}} \\
& =\frac{1}{\mathrm{R}_{i}+\mathrm{R}_{m}+\mathrm{R}_{f}+\mathrm{R}_{o}}
\end{aligned}
$$

Table 1. Input parameters of design.

\begin{tabular}{cccc}
\hline Parameter & Symbol & Unit & Value \\
\hline Total thermal power & $\mathrm{P}$ & $\mathrm{MW}$ & 968.3 \\
Coolant pressure & $\mathrm{P}_{\mathrm{p}}$ & $\mathrm{Mpa}$ & 15.5 \\
Coolant inlet temperature & $\mathrm{T}_{\mathrm{p}, \text { in }}$ & ${ }^{\circ} \mathrm{C}$ & 327.0 \\
Coolant outlet temperature & $\mathrm{T}_{\mathrm{p}, \text { out }}$ & ${ }^{\circ} \mathrm{C}$ & 310.0 \\
Average coolant temperature & $\mathrm{T}_{\mathrm{agv}}$ & ${ }^{\circ} \mathrm{C}$ & 23790.0 \\
Coolant flow rate & $\mathrm{Q}$ & $\mathrm{m}^{3} / \mathrm{h}$ & 4474 \\
Number of tubes & $\mathrm{N}$ & $\mathrm{n}$ & 226.0 \\
Feed water temperature & $\mathrm{T}_{\mathrm{s}, \text { in }}$ & 6.89 \\
Steam outlet pressure & $\mathrm{P}_{\text {steam }} \mathrm{C}$ & 282.9 \\
Steam outlet temperature & $\mathrm{T}_{\text {steam }}$ & $\mathrm{Mpa}$ & 538.40 \\
Steam outlet flow rate & $\mathrm{W}_{\text {steam }} \mathrm{C}$ & 0.0025 \\
Steam outlet wetness & $\mathrm{X}_{\mathrm{kg} / \mathrm{s}}$ & $8.80 \mathrm{E}-06$ \\
Fouling factor & $\mathrm{R}_{\text {fouling }}$ & ${ }^{\circ}$ & 0.01905 \\
Tube outside diameter & $\mathrm{d}_{\mathrm{o}}$ & $\mathrm{m}^{2} \cdot \mathrm{K} / \mathrm{W}$ & 0 \\
Tube wall thickness & $\delta$ & $\mathrm{m}$ & 0.01687 \\
Tube inside diameter & $\mathrm{d}_{\mathrm{i}}$ & $\mathrm{m}$ & 3.10 \\
Full load circulation ratio & & $\mathrm{m}$ & 5429.00 \\
Heat transfer area & $\mathrm{A}$ & $\mathrm{m}^{2}$ & \\
\hline
\end{tabular}


where $\alpha_{1}$ is the heat transfer coefficient inside the tube, $\mathrm{W} / \mathrm{m}^{2} \cdot \mathrm{K} ; \mathrm{R}_{\mathrm{i}}$ is the thermal resistance in the tube, $\mathrm{m}^{2} \cdot \mathrm{K} / \mathrm{W}$; $\alpha_{2}$ is the heat transfer coefficient outside the tube, $\mathrm{W} / \mathrm{m}^{2} \cdot \mathrm{K} ; \mathrm{R}_{0}$ is the thermal resistance outside the tube, $\mathrm{m}^{2} \cdot \mathrm{K} / \mathrm{W}$; $R_{w}$ is the Tube wall heat conduction thermal resistance, $m^{2} \cdot K / W ; R_{F}$ is the fouling resistance outside the tube, $\mathrm{m}^{2} \cdot \mathrm{K} / \mathrm{W} ; \mathrm{d}_{\mathrm{i}}, \mathrm{d}_{\mathrm{o}}$ and $\mathrm{d}_{\mathrm{e}}$ are the inner diameter, outer diameter and equivalent diameter of tube, respectively, $\mathrm{m}$. In this paper, equivalent diameter is equaled to the outer diameter.

The equation of logarithmic temperature difference (LMTD) of heat transfer logarithmic mean temperature difference is showed that:

$$
\Delta \mathrm{t}_{\mathrm{m}}=\frac{\Delta \mathrm{t}_{\max }-\Delta \mathrm{t}_{\min }}{\ln \left(\frac{\Delta \mathrm{t}_{\max }}{\Delta \mathrm{t}_{\min }}\right)}
$$

where $\Delta \mathrm{t}_{\max }$ and $\Delta \mathrm{t}_{\min }$ are the maximum temperature difference and minimum temperature difference, respectively, ${ }^{\circ} \mathrm{C}$.

The main task of design calculation is to calculate heat transfer temperature difference, determine the thermal resistance, obtain the overall coefficient of heat transfer, and the heat transfer area.

Along the flow direction of the primary side coolant in the U-shaped tube, according to the difference between the two coolant physical conditions, the heat exchange area can be divided into three sub regions (Figure 1). The secondary side coolants in the Region 1 and Region 3 belong to subcooled boiling, in the Region 2 belongs to saturated nucleate boiling [3]. The area can be calculated according to the regions in the fluid, or by assuming that the cold section is ignored. That's to say, partitional and overall calculation method can be employed. The two methods are compared in this paper.

\subsection{The Heat Transfer in Different Regions}

The critical point of the Region 2 and Region 1, 3 is the temperature when the coolant gets to saturation temperature. According to the energy conservation law, heat transfer energy $\mathrm{Q}_{1}$ or $\mathrm{Q}_{3}$ is equaled to the energy of heating the feed water from sub cooled temperature to the saturation temperature.

$$
\mathrm{Q}_{1}=\mathrm{Q}_{3}=\frac{1}{2} \cdot \mathrm{M}_{\mathrm{fs}} /\left(\mathrm{H}_{\mathrm{sat}}-\mathrm{H}_{\mathrm{fw}}\right)
$$

where $\mathrm{M}_{\mathrm{fs}}$ is the feed water flow rate, $\mathrm{kg} / \mathrm{s} ; \mathrm{H}_{\mathrm{sat}}$ is the feed water enthalpy at saturation temperature, $\mathrm{kJ} / \mathrm{kg}$; $\mathrm{H}_{\mathrm{fw}}$ is the feedwater enthalpy, $\mathrm{kJ} / \mathrm{kg}$.

The heat transfer energy of Region 2 is as follows:

$$
\mathrm{Q}_{2}=\mathrm{P}-\left(\mathrm{Q}_{1}+\mathrm{Q}_{3}\right)
$$

\subsection{The Calculation of Heat Transfer in the Primary Loop}

The equation of heat transfer in the primary loop is based on the McAdams formula [4]:

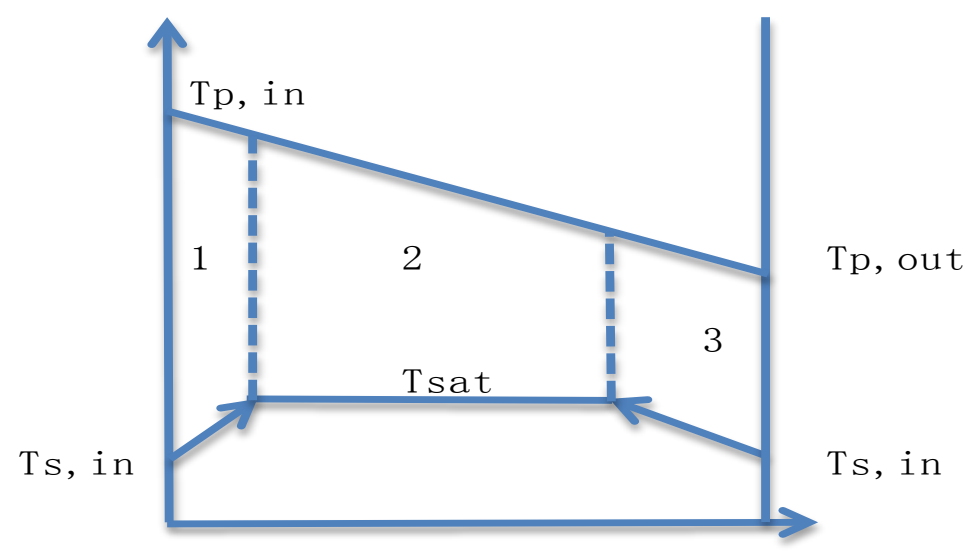

Figure 1. The division of heat transfer regions. 


$$
\mathrm{Nu}=0.023 \mathrm{Re}^{0.8} \operatorname{Pr}^{0.4}
$$

\subsection{The Calculation of Heat Transfer in the Secondary Loop}

The Jens-Lottes formula, Thom formula and Rohsenow formula are usually used to calculate the heat transfer of the secondary side loop.

The Jens-Lottes formula [4] is as follows:

$$
\begin{gathered}
\Delta T_{\text {sat }}=0.792037 q^{0.25} e^{-\frac{p}{6.2}} \\
\mathrm{R}_{2}=0.792037 q^{-0.75} e^{-\frac{p}{6.2}}
\end{gathered}
$$

where the unit of $\Delta \mathrm{T}$ is ${ }^{\circ} \mathrm{C}$; P, MPa; $\mathrm{q}, \mathrm{MW} / \mathrm{m}^{2} ; \mathrm{R}_{2}$ is thermal resistance outside the tube, $\mathrm{m}^{2} \cdot \mathrm{K} / \mathrm{W}$.

The Thom formula:

$$
\Delta \mathrm{T}_{\text {sat }}=0.0225 \mathrm{q}^{0.5} \mathrm{e}^{-\frac{\mathrm{p}}{8.7}}
$$

The Rohsenow formula [4]:

$$
\alpha=\left(\frac{C_{p, \mathrm{f}}}{h_{f g} \operatorname{Pr}^{m} C_{w 1}}\right)\left(\mu_{f} h_{f g} \sqrt{\frac{g\left(\rho_{f}-\rho_{g}\right)}{\sigma}}\right)^{0.33} q^{0.67}
$$

where the value of $m$ is equal to $1 ; \mathrm{C}_{\mathrm{w} 1}$ is 0.013 ; $\sigma$ is the surface tension, $\mathrm{Nm} ; \mathrm{C}_{\mathrm{p}, \mathrm{i}}$ is the specific heat capacity at constant pressure of saturated liquid, $\mathrm{J} /(\mathrm{kg} \cdot \mathrm{K}) ; \mathrm{h}_{\mathrm{fg}}$ is the latent heat of vaporization, $\mathrm{J} / \mathrm{kg} ; \mu_{\mathrm{f}}$ is the dynamic viscosity of saturated liquid, $\mathrm{Pa} \cdot \mathrm{s} ; \rho_{\mathrm{f}}$ and $\rho_{\mathrm{g}}$ are densities of the saturated liquid and vapor, respectively, $\mathrm{kg} / \mathrm{m}^{3}$; $\mathrm{Pr}$ is Prandtl constant of the saturated liquid.

Different companies employed different formulas to calculate the heat transfer in the secondary side loop. Western countries usually use Rohsenow formula [3]. But the Westinghouse used the revised Lottes Jens formula, Framatome used Thom formula.

\subsection{Thermal Resistance of the Tube Wall}

The equation of tube wall thermal conductivity is:

$$
\mathrm{R}_{\mathrm{w}}=\frac{\mathrm{de}}{2 \lambda_{\mathrm{w}}} \ln \frac{\mathrm{d}_{\mathrm{o}}}{\mathrm{d}_{\mathrm{i}}}
$$

where $\lambda_{\mathrm{W}}$ is the thermal conductivity of the tube materials, $\mathrm{W} / \mathrm{m}^{2} \cdot \mathrm{K}$. For Inconel-690, the coefficient of thermal conductivity varies with temperature (Table 2).

\subsection{Fouling Factor}

The fouling resistance is usually neglected as calculating the heat transfer coefficient. But a safety coefficient is considered when decides the heat transfer area. The primary loop water usually keeps highly clean, so the fouling resistance of the primary loop can be neglected. Due to the economy, the quality requirement of the secondary loop is not as strict as the primary loop. Therefore, a certain degree of deposit exists in the pipe of the secondary loop.

The steam generator fouling resistance was $528.8 \times 10^{-7} \mathrm{~m}^{2} \cdot \mathrm{K} / \mathrm{W}$ recommended by George [5], and the fouling resistance of Bristol used for steam generator of nuclear power plant A is $257.94 \times 10^{-7} \mathrm{~m}^{2} \cdot \mathrm{K} / \mathrm{W}$. 55/19 steam generator's fouling resistance in Daya Bay nuclear power plant is $88 \times 10^{-7} \mathrm{~m}^{2} \cdot \mathrm{K} / \mathrm{W}$ [4]. The design value of steam generator $60 \mathrm{~F}$ is $134 \times 10^{-7} \mathrm{~m}^{2} \cdot \mathrm{K} / \mathrm{W}$ in the second phase of Qinshan nuclear power plant [6]. The de-

Table 2. Thermal conductivity of Inconel-690 at different temperature.

\begin{tabular}{ccccccc}
\hline Temperature & ${ }^{\circ} \mathrm{C}$ & 100 & 200 & 300 & 400 \\
\hline Thermal conductivity & $\mathrm{W} /(\mathrm{m} \cdot \mathrm{K})$ & 13.5 & 15.1 & 17.3 & 19.1 & 21 \\
\hline
\end{tabular}


sign fouling factor of steam generator AP1000 is $193.89 \times 10^{-7} \mathrm{~m}^{2} \cdot \mathrm{K} / \mathrm{W}[7]$.

\section{Calculation Results}

The parameters of steam generator 55/19, including thermal power, heat transfer coefficient and LMTD are calculated based on the models in this paper. And the results are showed in Table 3.

The calculated heat transfer coefficients are different when using different models. The heat transfer coefficient from the Jens model is larger than the Rohsenow model, whereas the Thom model is the smallest. For the calculated heat transfer area, the results are in an opposite order. That is to say, the calculated area based on the Thom model is the largest, whereas the Jens model is the smallest.

The area deviation between the Jens model and the design value was $10 \%$, which meets the requirement of the tube plugging margin (10\%) in normal design of steam generator. The calculation errors are $1.33 \%$ and $0.64 \%$ compared with the design value when using the Jens model. It can be seen that the area deviation between the partitional coverall calculation methods was small. So the simple overall calculation method is usually used in the engineering design, and the preheating section can be neglected.

The distribution of four resistances between the partitional and overall calculation methods displayed in Figure 2 and Figure 3 based on the Jens modes. It concludes that thermal resistance of the tube wall is the largest among the four resistances, and the percentage is $57 \%$. The percentages of the thermal resistance inside and outside the tube are $24 \%$ and $11 \%$, respectively. The fouling factor is the smallest, $8 \%$.

Table 3. The results of partitional and overall calculation methods.

\begin{tabular}{|c|c|c|c|c|c|c|}
\hline \multirow{2}{*}{ Parameters } & \multirow{2}{*}{ Symbol } & \multirow{2}{*}{ Unit } & \multicolumn{3}{|c|}{ Partitional calculation method } & \multirow{2}{*}{$\begin{array}{c}\text { Overall } \\
\text { calculation } \\
\text { method }\end{array}$} \\
\hline & & & Region 1 & Region 2 & Region 3 & \\
\hline Thermal power & $\mathrm{P}$ & MW & 75.23 & 817.86 & 75.23 & 968.33 \\
\hline Tube ID resistance & $\mathrm{R}_{\mathrm{i}}$ & $\mathrm{m}^{2} \cdot \mathrm{K} / \mathrm{W}$ & $2.68 \mathrm{E}-05$ & $2.66 \mathrm{E}-05$ & $2.63 \mathrm{E}-05$ & $2.74 \mathrm{E}-05$ \\
\hline Tube wall resistance & $\mathrm{R}_{\mathrm{m}}$ & $\mathrm{m}^{2} \cdot \mathrm{K} / \mathrm{W}$ & $6.51 \mathrm{E}-05$ & $6.52 \mathrm{E}-05$ & $6.73 \mathrm{E}-05$ & $6.51 \mathrm{E}-05$ \\
\hline \multirow[t]{2}{*}{ Fouling factor } & $\mathrm{R}_{\mathrm{f}}$ & $\mathrm{m}^{2} \cdot \mathrm{K} / \mathrm{W}$ & $8.80 \mathrm{E}-06$ & $8.80 \mathrm{E}-06$ & $8.80 \mathrm{E}-06$ & $8.80 \mathrm{E}-06$ \\
\hline & Ro-R & $\mathrm{m}^{2} \cdot \mathrm{K} / \mathrm{W}$ & $1.30 \mathrm{E}-05$ & $1.99 \mathrm{E}-05$ & $3.79 \mathrm{E}-05$ & $2.12 \mathrm{E}-05$ \\
\hline \multirow[t]{3}{*}{ Tube OD resistance } & Ro-T & $\mathrm{m}^{2} \cdot \mathrm{K} / \mathrm{W}$ & $1.71 \mathrm{E}-05$ & $2.35 \mathrm{E}-05$ & $3.74 \mathrm{E}-05$ & $2.45 \mathrm{E}-05$ \\
\hline & Ro-J & $\mathrm{m}^{2} \cdot \mathrm{K} / \mathrm{W}$ & $7.72 \mathrm{E}-06$ & $1.23 \mathrm{E}-05$ & $2.47 \mathrm{E}-05$ & $1.31 \mathrm{E}-05$ \\
\hline & $\mathrm{K}-\mathrm{R}$ & $\mathrm{W} / \mathrm{m}^{2} \cdot \mathrm{K}$ & 8794.25 & 8293.74 & 7123.17 & 8166.20 \\
\hline \multirow[t]{2}{*}{$\begin{array}{l}\text { Heat transfer } \\
\text { Coefficient }\end{array}$} & $\mathrm{K}-\mathrm{T}$ & $\mathrm{W} / \mathrm{m}^{2} \cdot \mathrm{K}$ & 8488.42 & 8056.59 & 7148.53 & 7947.01 \\
\hline & K-J & $\mathrm{W} / \mathrm{m}^{2} \cdot \mathrm{K}$ & 9224.86 & 8855.24 & 7863.01 & 8739.86 \\
\hline Inlet temperature of primary loop & $\mathrm{T}_{\mathrm{p}, \text { in }}$ & ${ }^{\circ} \mathrm{C}$ & 327.60 & 325.16 & 295.30 & 327.60 \\
\hline Outlet temperature of primary loop & $\mathrm{T}_{\mathrm{p}, \text { out }}$ & ${ }^{\circ} \mathrm{C}$ & 325.16 & 295.30 & 292.30 & 292.30 \\
\hline Inlet temperature of secondary loop & $\mathrm{T}_{\mathrm{s}, \mathrm{in}}$ & ${ }^{\circ} \mathrm{C}$ & 265.50 & 282.94 & 282.94 & 265.50 \\
\hline Outlet temperature of secondary loop & $\mathrm{T}_{\mathrm{s}, \text { out }}$ & ${ }^{\circ} \mathrm{C}$ & 282.94 & 282.94 & 265.50 & 282.94 \\
\hline LMTD & $\Delta \mathrm{Tm}$ & ${ }^{\circ} \mathrm{C}$ & 43.42 & 24.30 & 10.79 & 22.59 \\
\hline \multirow{3}{*}{$\begin{array}{l}\text { Heat transfer } \\
\text { area }\end{array}$} & $A-R$ & $\mathrm{~m}^{2}$ & 197.00 & 4057.71 & 979.05 & 5249.63 \\
\hline & $\mathrm{A}-\mathrm{T}$ & $\mathrm{m}^{2}$ & 204.10 & 4177.15 & 975.58 & 5394.42 \\
\hline & A-J & $\mathrm{m}^{2}$ & 187.81 & 3800.41 & 886.93 & 4905.06 \\
\hline \multirow{4}{*}{$\begin{array}{l}\text { Total area of } \\
\text { heat transfer }\end{array}$} & A-R & $\mathrm{m}^{2}$ & & 5233.77 & & 5249.63 \\
\hline & $A-T$ & $\mathrm{~m}^{2}$ & & 5356.83 & & 5394.42 \\
\hline & A-J & $\mathrm{m}^{2}$ & & 4875.15 & & 4905.06 \\
\hline & $\delta$-R & & & 3.60 & & 3.30 \\
\hline \multirow[t]{2}{*}{$\begin{array}{l}\text { The area deviation } \\
\text { between the calculation and design }\end{array}$} & $\delta$-T & & & 1.33 & & 0.64 \\
\hline & $\delta$-J & & & 10.20 & & 9.65 \\
\hline
\end{tabular}




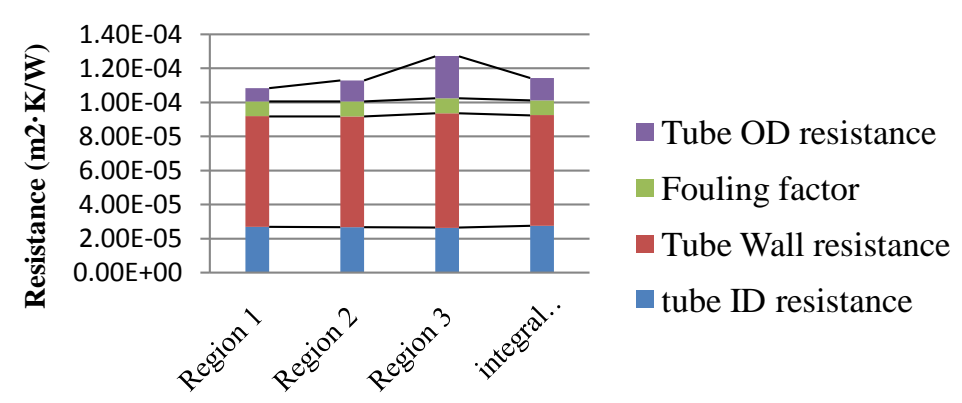

Figure 2. The distribution of four resistances between the partitional and overall calculation methods.

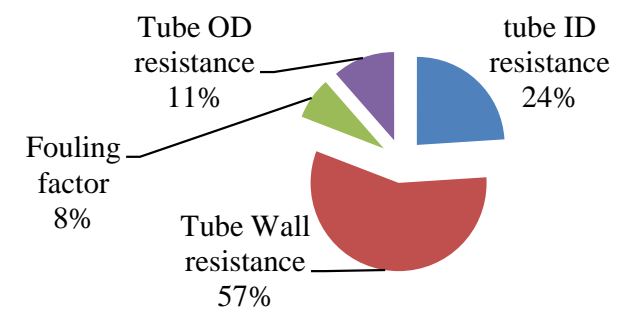

Figure 3. The distribution of four resistances from the overall calculation method.

\section{Conclusions}

There are small area deviations between the partitional and overall calculation method. The overall calculation method which usually can be used in the engineering design neglected the preheating section.

The thermal resistance of tube wall is the largest among the four resistances, then the inside and outside of the tube. The fouling resistance is the smallest.

The computation of heat transfer area is one of most important content in steam generator design. Once the heat transfer area of the steam generator is accurately calculated, the structure of the steam generator, including the tube sheet size, the U-tube height and the tube support plate shape, can be well designed.

In this paper, the heat transfer area was calculated for the steam generator 55/19. The deviation between the calculated area and the design value can be neglected. It indicates that the model used in calculation process is proper and correct. The research work is very promising for the design of steam generator with independent intellectual property rights.

\section{References}

[1] Guangdong Nuclear Power Joint Venture (1986) 55/19 Steam Generator Thermal Hydraulic Design Studies.

[2] Steam Generator Compiling Group (1982) The Steam Generator. Atomic Energy Press.

[3] Wang, W. (2013) Calculation of Heat Transfer Area for CPR1000 Steam Generator. Dong Fang Electric Review, 27, 53-55.

[4] Suzhou Nuclear Power Institute (2014) The Research of CPR1000 Unit Steam Generator. Suzhou.

[5] Ding, X.S. (2000) Chemical Cleaning and Heat Transfer Performance of Steam Generator of Nuclear Power Plant. The Cleaning World, 7, 17-22.

[6] Westinghouse Electric Company, WNEP-9722 (1997) Mode 60F Steam Generator Thermal and Hydraulic Design Data Report. Qinshan II Nuclear Power Project Units 1 and 2.

[7] Lin, C.G., Yu, Z.S. and Yu, O.Y. (2012) AP1000 for Passive Advanced Nuclear Power Plant. Atomic Energy Press. 